\title{
Literature Values of Terminal Half-Lives of Clozapine are Dependent on the Time of the Last Data Point
}

Jim Fang ${ }^{1}$ and Karen E. Mosier ${ }^{2}$

${ }^{1}$ College of Pharmacy and Nutrition, University of Saskatchewan, Saskatoon, SK, Canada

${ }^{2}$ Western College of Veterinary Medicine, University of Saskatchewan, Saskatoon, SK, Canada

Received, December 6, 2013; Revised, February 16, 2014; Accepted, April 10, 2014; Published, April 13, 2014.

Dear Editor,

During a pharmacokinetic study involving clozapine, we noticed different terminal half-lives for clozapine when the time of the last data point was changed. To validate this notion, a systematic literature search was conducted in PubMed and Google Scholar for the terminal half-life values of clozapine in humans. Twenty-one publications were identified to contain terminal half-life information of clozapine when it was administered alone (Table 1). The average literature values of the terminal half-lives of clozapine were calculated to be 10.2,
13.2, 14.2, 18.3 and 29.2 hours with a last data point at 12, 24, 48, 72 and 120 hours, respectively (Table 1). Thus, there is a trend to find a longer terminal half-life when longer blood sampling times are used in pharmacokinetic studies on clozapine in humans.

Corresponding Author: Dr. Jim Fang, College of Pharmacy and Nutrition, University of Saskatchewan, Saskatoon, Saskatchewan, Canada; Email: jim.fang@usask.ca

Table 1. Literature values of terminal half-lives of clozapine in humans with different times for the last data point

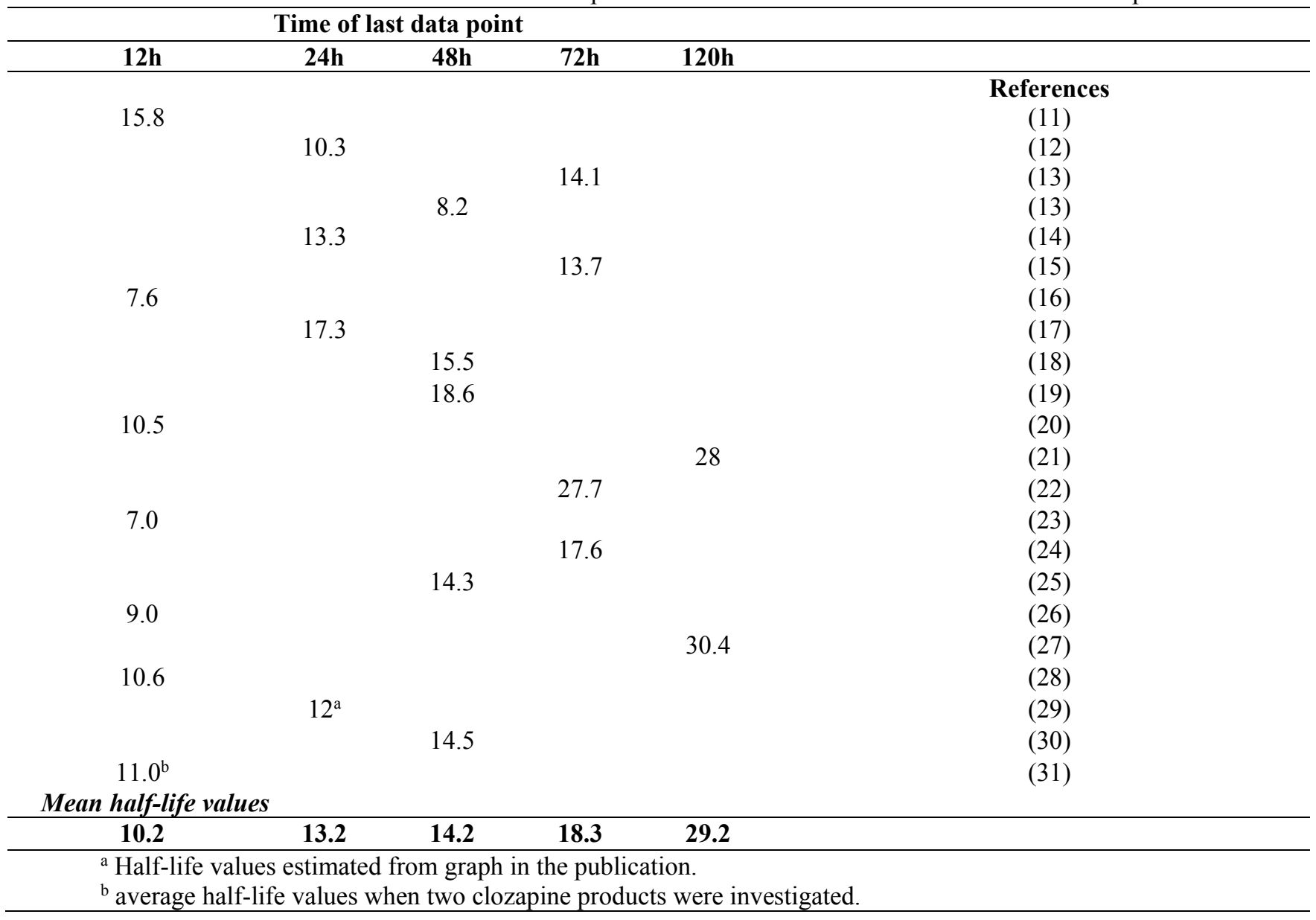


Clozapine treatment is effective in $30 \%$ to $38 \%$ of treatment-resistant schizophrenic patients (1). Many pharmacokinetic studies and case reports have been published on clozapine because clozapine has a narrow therapeutic window and increased plasma concentrations of clozapine can lead to serious side effects such as toxic delirium and sedation (2) or convulsions (at plasma concentrations above $1300 \mathrm{ng} / \mathrm{ml}$ ) (3).

A one compartment model is often assumed in calculating the half-lives of therapeutic agents because the differences are important only if the fraction of the dose lingering at the end of a dose interval is substantial so that it can influence the steady-state concentrations. However, differences in reported half-life values may influence clinical decisions on dose regimens of clozapine. This matter could be further complicated by the numerous drug-drug interactions reported during its clinical use (4-6). Most of these interactions are due to inhibition or induction of cytochrome P450 enzymes responsible for the metabolism of clozapine (7-9). It is however worth noting the relatively small differences in half-lives when the last data points were 12, 24 and 48 hours.

"Terminal half-lives" of therapeutic agent are routinely computed and reported in the literature. However, terminal half-lives are constant only when there is a clear log-linear phase. Thus, for drugs with a third deep compartment such as clozapine, one should remember to consider the time of the last data point when comparing the terminal half-life. Similar cases may also exist in the literature for other therapeutical agents (10).

\section{REFERENCES}

1. Kane J, Honigfeld G, Singer J, and Meltzer H. Clozapine for the treatment-resistant schizophrenic. A double-blind comparison with chlorpromazine. Arch Gen Psychiatry, 45:789-796, 1988.

2. Fitton A and Heel RC. Clozapine. A review of its pharmacological properties, and therapeutic use in schizophrenia. Drugs, 40:722-747, 1990.

3. Simpson GM and Cooper TA. Clozapine plasma levels and convulsions. Am J Psychiatry, 135:99100, 1978.

4. Bitter R, Demler TL, and Opler L. Safety evaluation of the concomitant use of clozapine and benzodiazepines: a retrospective, cross-sectional chart review. J Psychiatr Pract, 14:265-270, 2008.

5. Wetzel H, Anghelescu I, Szegedi A, Wiesner J, Weigmann $\mathrm{H}$, Harter $\mathrm{S}$, and Hiemke C.
Pharmacokinetic interactions of clozapine with selective serotonin reuptake inhibitors: differential effects of fluvoxamine and paroxetine in a prospective study. J Clin Psychopharmacol, 18:2-9, 1998.

6. Taylor D. Pharmacokinetic interactions involving clozapine. Br J Psychiatry, 171:109-112, 1997.

7. Eiermann B, Engel G, Johansson I, Zanger UM, and Bertilsson L. The involvement of CYP1A2 and CYP3A4 in the metabolism of clozapine. Br J Clin Pharmacol, 44:439-446, 1997.

8. Fang J, Coutts RT, McKenna KF, and Baker GB. Elucidation of individual cytochrome P450 enzymes involved in the metabolism of clozapine. Naunyn Schmiedebergs Arch Pharmacol, 358:592-599, 1998.

9. Fischer V, Vogels B, Maurer G, and Tynes RE. The antipsychotic clozapine is metabolized by the polymorphic human microsomal and recombinant cytochrome P450 2D6. J Pharmacol Exp Ther, 260:1355-1360, 1992.

10. Jamali F, Alballa RS, Mehvar R, and Lemko CH. Longer plasma half-life for procainamide utilizing a very sensitive high performance liquid chromatography assay. Ther Drug Monit, 10:91-96, 1988.

11. Choc MG, Lehr RG, Hsuan F, Honigfeld G, Smith HT, Borison R, and Volavka J. Multiple-dose pharmacokinetics of clozapine in patients. Pharm Res, 4:402-405, 1987.

12. Cheng YF, Lundberg T, Bondesson U, Lindstrom L, and Gabrielsson J. Clinical pharmacokinetics of clozapine in chronic schizophrenic patients. Eur J Clin Pharmacol, 34:445-449, 1988.

13. Choc MG, Hsuan F, Honigfeld G, Robinson WT, Ereshefsky L, Crismon ML, Saklad SR, Hirschowitz $\mathrm{J}$, and Wagner R. Single- vs multiple-dose pharmacokinetics of clozapine in psychiatric patients. Pharm Res, 7:347-351, 1990.

14. Dahl ML, Llerena A, Bondesson U, Lindstrom L, and Bertilsson L. Disposition of clozapine in man: lack of association with debrisoquine and $\mathrm{S}$ mephenytoin hydroxylation polymorphisms. $\mathrm{Br} \mathrm{J}$ Clin Pharmacol, 37:71-74, 1994.

15. Lin SK, Chang WH, Chung MC, Lam Y, and Jann MW. Disposition of clozapine and desmethylclozapine in schizophrenic patients. J Clin Pharmacol, 34:318-324, 1994.

16. Guitton C, Abbar M, Kinowski JM, Chabrand P, and Bressolle F. Multiple-dose pharmacokinetics of clozapine in patients with chronic schizophrenia. $\mathrm{J}$ Clin Psychopharmacol, 18:470-476, 1998.

17. Chang WH, Lin SK, Lane HY, Wei FC, Hu WH, Lam YW, and Jann MW. Reversible metabolism of clozapine and clozapine N-oxide in schizophrenic patients. Prog Neuropsychopharmacol Biol Psychiatry, 22:723-739, 1998. 
18. Chang WH, Augustin B, Lane HY, ZumBrunnen T, Liu HC, Kazmi Y, and Jann MW. In-vitro and invivo evaluation of the drug-drug interaction between fluvoxamine and clozapine. Psychopharmacology (Berl), 145:91-98, 1999.

19. Hagg S, Spigset O, Mjorndal T, Granberg K, Persbo-Lundqvist G, and Dahlqvist R. Absence of interaction between erythromycin and a single dose of clozapine. Eur J Clin Pharmacol, 55:221-226, 1999.

20. Guitton C, Kinowski JM, Abbar M, Chabrand P, and Bressolle F. Clozapine and metabolite concentrations during treatment of patients with chronic schizophrenia. J Clin Pharmacol, 39:721728, 1999.

21. Wang C, Zhao J, and Chen Y. The pharmacokinetics of clozapine correlated with a caffeine test. Chin J Psychiatry, 33:16-19, 2000.

22. Wang CY, Zhang ZJ, Li WB, Zhai YM, Cai ZJ, Weng YZ, Zhu RH, Zhao JP, and Zhou HH. The differential effects of steady-state fluvoxamine on the pharmacokinetics of olanzapine and clozapine in healthy volunteers. J Clin Pharmacol, 44:785-792, 2004.

23. Tassaneeyakul W, Kittiwattanagul K, Vannaprasaht S, Kampan J, Tawalee A, Puapairoj P, Tiamkao S, Juthagridsada S, and Kukongviriyapan V. Steadystate bioequivalence study of clozapine tablet in schizophrenic patients. J Pharm Pharm Sci, 8:47-53, 2005.

24. Golden $G$ and Honigfeld G. Bioequivalence of clozapine orally disintegrating $100-\mathrm{mg}$ tablets compared with clozapine solid oral 100-mg tablets after multiple doses in patients with schizophrenia. Clin Drug Investig, 28:231-239, 2008.
25. Liu X-y, Wang B-j, Wei C-m, Yuan G-y, Li R, and Guo R-c. Study on bioequivalence of clozapine dispersible tablets in healthy volunteers. Chin J Hosp Pharm, 16:010, 2009.

26. Tassaneeyakul W, Kittiwattanagul K, Tiamkao S, Kampan J, Vannaprasaht S, Haewdee W, Puapairoj $\mathrm{P}$, Kongyingyoes $\mathrm{B}$, and Tassaneeyakul W. Bioequivalence of Clozapine Tablet in Thai Schizophrenic Patients. Srinagarind Med J, 22:1623, 2010.

27. Chatsiricharoenkul S, Niyomnaitham S, Pongnarin $\mathrm{P}$, Sathirakul K, and Kongpatanakul S. Bioequivalence Study of $10 \mathrm{mg}$ Olanzapine Tablets in Healthy Thai Volunteers. J Bioequiv Availab, 3:082-085, 2011.

28. Liu X, Huang R-b, Huang J-x, Qiu C, Zhang M, and Wen Y-g. Study on bioequivalence of clozapine orally disintegrating tablets in patients with schizophrenia. Chin J Hosp Pharm, 23:010, 2011.

29. Glue P, Gale C, Menkes DB, and Hung N. Evaluation of Bioequivalence Between Clozapine Suspension and Tablet Formulations. Clin Drug Investig, 32:723-727, 2012.

30. Liu Y, Li H, and Yan M. Individual Differences in The Pharmacokinetics of Clozapine in Healthy Chinese Adults. Bull Clin Psychopharmacol, 22:1722, 2012.

31. do Carmo Borges NC, Astigarraga RB, Sverdloff CE, Galvinas PR, Borges BC, and Moreno RA. Comparative bioavailability of two oral formulations of clozapine in steady state administered in schizophrenic volunteers under individualized dose regime. Curr Clin Pharmacol, 7:241-253, 2012. 